\title{
Upaya Mewujudkan Desa Open Defecation Free di Desa Pojok Kecamatan Garum Kabupaten Blitar
}

\author{
Siti Uswatun Kasanah ${ }^{(1)}$ \\ ${ }^{1}$ Universitas Nahdlatul Ulama Blitar \\ Email: ${ }^{1}$ uswahunublitar@gmail.com
}

$\overline{\text { Tersedia Online di }}$
http://www.jurnal.unublitar.ac.id/
index.php/briliant

Sejarah Artikel

Diterima pada 22 Juli 2018

Disetuji pada 9 Agustus 2018

Dipublikasikan pada 13 Agustus

2018 Hal. 354-364

\section{Kata Kunci:}

open defecation free, desa pojok, blitar,

\section{DOI:}

http://dx.doi.org/10.28926/briliant .$v 3 i 3.209$

\begin{abstract}
Abstrak: Tujuan penelitian untuk mengetahui demografi dan sosiologi masyarakat Desa Pojok Kecamatan Garum serta upaya mewujudkan desa Open Defecation Free (ODF) di Desa Pojok Kecamatan Garum blitar. Metode penelitian menggunakan jenis penelitian kualitatif, dengan aksi partisipatif (participatory action research), Hasil penelitian menunjukan bahwa upaya mewujudkan Desa Open Defecation Free (ODF) di Desa Pojok Kecamatan Garum Kabupaten Blitar dilakukan melalui beberapa cara antara lain memberdayakan masyarakat melalui pembentukan kelompok desa (Pokja) Simpatik, sosialisasi Open Defecation Free (ODF), pemetaan dan pemicuan Jamban keluarga. Kesimpulan bahwa demografi masyarakat Desa Pojok masih berpendidikan menengah dan rendah, Sosiologi masyarakat didominasi petani dengan lingkungan pedesaan, sedangkan upaya mewujudkan Open Defecation Free (ODF) dilakukan dengan bekerjasama semua pihak guna meningkatkan kehidupan sosial masyarakat yang lebih beradab dan bermartabat.
\end{abstract}

Kesehatan adalah kebutuhan manusia yang sangat mendasar. Kesehatan juga menjadi salah satu unsur penting dari tercapainya kesejahteraan umum sebagaimana termaktub dalam UUD 1945 yang kemudian dimanifestasikan dalam bentuk pembangunan nasional berkelanjutan. Hal ini juga selaras dengan poin ketiga dalam Sustainable Development Goals yang dicetuskan oleh United Nations Development Program (UNDP) yaitu memastikan hidup sehat dan mempromosikan kesejahteraan untuk semua di segala usia (Osborn et all., 2015:6). Konsep ini merupakan kelanjutan dari program Millenium Development Goals yang telah berjalan sebelumnya (UNDESA, 2007:7). Namun proses pembangunan nasional khususnya di sektor kesehatan ternyata mengalami berbagai hambatan, baik hambatan yang berasal dari keterbatasan negara maupun keterbatasan masyarakat. Terkait dengan keterbatasan masyarakat, salah satu hal yang paling mendasar adalah rendahnya kesadaran masyarakat terutama di wilayah pedesaan akan pentingnya lingkungan yang bersih dan sehat. Kurangnya kesadaran tersebut dapat dilihat secara nyata dari kebiasaan masyarakat pedesaan buang air besar di sembarang tempat seperti di daerah aliran sungai, seperti di desa Pojok Kecamatan Garum Kabupaten Blitar.

Kebersihan juga merupakan salah salah satu pokok dalam memelihara kelangsungan eksistensinya, sehingga tidak ada satupun makhluk kecuali berusaha untuk membersihkan dirinya. Bersih adalah kondisi sesuatu yang bebas dari hal yang kotor. Jadi benda yang di katakan bersih apabila tidak ada kotoran berupa 
apa pun. Maka dari pengertian ini dapahi diketahui bahwa kondisi bersih berarti sesuatu hal yang harus dijaga dan dirawat dari hal-hal yang kotor yang dapat dihinggapi oleh kuman serta menjadi sarang penyakit.

Ditambah lagi pada tahun 2016 Desa Pojok masih belum berstatus Open Defecate Free (ODF) dari jumlah total 7 dusun di Desa Pojok Kecamatan Garum Kabupaten Blitar. Namun ironisnya tak satu dusunpun yang susah mendukung terwujudnya desa Open Defecate Free (ODF). Desa tersebut berada diwilayah kerja Puskesmas Kecamatan Garum. Bila diidentifikasikan secara lebih terperinci, ada beberapa faktor yang menjadi penyebab mengapa tak satu dusunpun di wilayah kerja Puskesmas Garum tersebut menyandang predikat Open Defecate Free (ODF). Pertama, secara geografis wilayah kerja Puskesmas Garum tepatnya setiap dusun pemukiman warga dibentangi oleh sungai dan sempalan-sempalan sungai kecil yang sangat mendukung kebiasaan masyarakat untuk buang air besar di sembarang tempat khususnya sungai. Kondisi tersebut membuat masyarakat mengambil jalan pintas saja dengan berak di sungai dan atau di persawahan. Terlebih banyak warga yang pemukimannya di lalui sungai beraktivitas setiap hari dengan membuang sampah, mencuci, bahkan mandi di sungai tersebut. Akibatnya lingkungan tercemari limbah organik berupa feses manusia dan juga limbah anorganik dari sampah rumah tangga lainnya yang juga dibuang di sungai tersebut. Hal tersebut telah berlangsung bertahun-tahun hingga menjadi kebiasaan.

Definisi Demografi adalah studi ilmiah tentang penduduk, terutama tentang jumlah, sturuktur dan perkembangannya. (Sururudin, 2008). Penduduk adalah hasil tingkat kelahiran, tingkat migrasi dan tingkatkematian. Demograsi lajim digunakan untuk mnyebut studi tentang sifat terhadap komposisi dan pertumbuhan penduduk.dan demograsi adalah suatu studi statistik dan matematis tentang jumlah, komposisi san persebaran penduduk, serta perubahan faktor faktor ini setelah melewati kurun waktu yang yang disebabkan oleh lima proses yaitu fertilitas, moralitas, perkawinan, migrasi dan mobilitas sosial.

Para sarjana Berikut beberapa definisi masyarakat dari para ilmuan antara lain: (1) M. J. Herskovits menyatakan bahwa Masyrakat adalah kelompok individu yang diorganisasikan dan mengikuti satu cara hidup tertentu. (2) J.L.Gillin dan J.P.Gillin menjelaskan bahwa Masyarakat adalah kelompok manusia yang tersebar dan mempunyai kebiasaan, tradisi, sikap, dan perasaan persatuan yang sama. Masyarakat itu meliputi pengelompokkan-pengelompokkan yang lebih kecil, sedangkan (3)R.Linton berpendapat bahwa Masyarakat adalah setiap kelompok manusia yang telah cukup lama hidup dan bekerja sama, sehingga mereka ini dapat mengorganisasikan dirinya berpikir tentang dirinya dalam suatu kesatuan sosial dengan batas-batas tertentu. (Harwantiyoko \& F, KN. 1997).

Sedangkan definisi masyarakat desa menurut Sutardjo Kartohadi Kusuma adalah suatu kesatuan hukum di mana bertempat tinggal suatu masyarakat pemerintahan sendiri. Bintarto mendefinisikan bahwa desa merupakan perwujudan atau kesatuan geografi, social, ekonomi, politik dan kultural yang terdapat di situ (suatu daerah) dalam hubungannya dan pengaruhnya secara timbal-balik dengan daerah lain. Sedangkan menurut Paul h. Landis, desa adalah penduduknya kurang dari 2.500 jiwa. Masyarakat desa adalah komunitas yang 
tinggal di dalam satu daerah yang sama, yang bersatu dan bersama-sama, memiliki ikatan yang kuat dan sangat mempengaruhi satu sama lain. (Wilujeng, 2012).

Hal ini dikarenakan pada masyarakat desa tradisi itu masih sangat kuat dan kental. Bahkan terkadang tradisi ini juga sangat mempengaruhi perkembangan desa, karena terlalu tinggi menjunjung kepercayaan nenek moyang mengakibatkan sulitnya untuk melakukan pembaharuan desa. Dengan demikian dapat disimpulkankan bahwa demografi masyarakat desa yaitu suatu studi ilmiah tentang penduduk, jumlah, struktur dan perkembanganya yang berada di wilayah desa.

Adapun ciri-ciri desa yaitu sebagai berikut: (1) Di dalam masyarakat pedesaan memiliki hubungan yang lebih mendalam dan erat bila dibandingkan dengan masyarakat pedesaan lainnya di luar batas-batas wilayahnya; (2) System kehidupan umumnya berkelompok dengan dasar kekeluargaan (gemeinschaft atau paguyuban); (3) Sebagian besar warga masyarakat hidup dari pertanian. Pekerjaan-pekerjaan yang bukan pertanian merupakan pekerjaan sambilan (part time) yag biasa mengisi waktu luang; (4) Masyarakat tersebut homogen, seperti dalam hal mata pencaharian, agama, adat-istiadat dan sebagainya. (Wilujeng, 2012)

Sedangkan sosiologi masyarakat desa secara terminologi 'sosiologi' (1839) berasal dari bahasa Latin, yakni kata socius yang berarti ' kawan', berkawan, ataupun 'bermasyarakat'. Sedangkan 'logos yang berarti "kata" atau "berbicara" jadi sosiologi berarti berbicara mengenai masyarakat", Untuk mencagkup semuanya bahwa sosiologi mempelajari struktur sosial dan prosesproses sosial,termasuk di dalamnya perubahan-perubahan social.(Soemarjan 1964).

Beberapa pendapat tentang Sosiologi masyarakat yaitu: a)Menurut T. Lynn Smith dan Paul E. Zapt menguraikan bahwa sosiologi pedesaan adalah kumpulan pengetahuan yang telah disistematisasi yang dihasilkan lewat penerapan metode ilmiah ke dalam studi tentang masyarakat pedesaan, struktur organisasinya, proses-prosesnya, sistem sosialnya yang pokok dan perubahanperubahannya (Rahardjo, 1999); b)Menurut Jhon M. Gillette (1922:6) Sosiologi pedesaaan adalah cabang sosiologi yang secara sistematis mempelajari komunitaskomunitas pedesaan untuk mengungkapkan kondisi-kondisi serta kecenderungankecenderungannya dan merumuskan prinsip-prinsip kemajuan.; c)Sosiologi pedesaan merupakan studi yang melukiskan hubungan manusia di dalam dan antar kelompok yang ada di lingkungan pedesaan (Priyo Tamtomo, 2001); d)Sosiologi pedesaan didefinisikan sebagai ilmu yang mempelajari fenomena masyarakat dalam setting pedesaan (Rogers); e)Sosiologi pedesaan adalah studi tentang hubungan manusia dalam lingkungan pedesaan (Bertand); f)Sosiologi pedesaan adalah studi tentang penduduk pedesaan, organisasi sosial pedesaan dan prosesproses sosial komparatif, dalam masyarakat pedesaan (F. Stuard Chapin); g)Sosiologi pedesaan adalah ilmu masyarakat pedesaan. Dikemukakan pula bahwa sosiologi pedesaan merupakan ilmu tentang hukum perkembangan masyarakat pedesaan (AR Desai); h)Sosiologi pedesaan adalah ilmu kemasyarakatan yang mempelajari kehidupan di lingkungan pedesaan (D. Samderson); i)NL.Sims (dalam Rahardjo, 1999), mengemukakan bahwa sosiologi pedesaan adalah studi tentang asosiasi persekutuan antara orang-orang yang

356 BRILIANT: Jurnal Riset dan Konseptual Volume 3 Nomor 3, Agustus 2018 
hidupnya lebih kurang tergantung pada pertanian. (https://tipsserbaserbi. blogspot.co.id).

Sedangkan ciri-ciri yang mencolok pada masyarakat pedesaan meliputi: (1) jumlah penduduk di perkotaan jauh lebih padat dibandingkan dengan di pedesaan, lingkungan hidup di di pedesaan yang sangat tradisional; (2) mata pencaharian di pedesaan masih mengandalkan alam sekitar desa, seperti nelayan, petani, peternak hewan; corak masyarakat desa sangat mengutamakan sosial live nya; Pola interaksi sosisal antara dua individu atau lebih dimana kelakuan individu yang satu mempengaruhi, mengubah, atau memperbaiki kelakuan individu lain atau sebaliknya. (Kristiyanto, 2017).

Prilaku masyarakat desa yang cenderung tergantung oleh keadaan alam tentu ada nilai positifnya, namun dalam hal kebiasaan memanfaatkan Sungai sebagai tempat buang air besar perlu dicegah dan dilakukan sosialisasi untuk menssukseskan program "Pemilikan Jamban Sehat Keluarga (PJSK)" yang mampu dapat dilakukan oleh masyarakat desa untuk mendapatkan jamban sehat. Dengan upaya tersebut diharapkan upaya-upaya untuk merintis desa Open Defecation Free (ODF) dapat mulai bermunculan.

Kemudian istilah Open Defecation Free (ODF) merupakan cakupan dalam Sanitasi Total Berbasis Masarakat (STBM) adalah kondisi ketika setiap individu dalam komunitas tidak buang air besar sembarangan, Pembuangan tinja yang tidak memenuhi syarat sangat berpengaruh pada penyebaran penyakit berbasis lingkungan, sehingga untuk memutuskan rantai penularan ini harus dilakukan rekayasa pada akses ini. Agar usaha tersebut berhasil, akses masyarakat pada jamban (sehat) harus mencapai $100 \%$ pada seluruh komunitas. Sedangkan Desa/Kelurahan ODF (Open Defecation Free) adalah Desa/kelurahan yang 100\% masyarakatnya telah buang air besar di jamban sehat, yaitu mencapai perubahan perilaku kolektif terkait Pilar 1 dari 5 pilar Sanitasi Total Berbasis Masyarakat. (http://warungbidan.blogspot.co.id).

Kata ODF merupakan kepanjangan dari Open Defecation Free (ODF) Surat Edaran berdasar dari Keputusan Menteri Kesehatan No.132 tahun 2013 tentang Pelaksanaan Sanitasi Total Berbasis Masyarakat (STBM). (Kepmenkes No 852 tahun 2008). Hal tersebut telah dijelaskan bahwa program nasional STBM telah berjalan sejak tahun 2008, namun masih banyak daerah yang enggan ataupun ragu melaksanakannya dengan berbagai argumen. Meskipun Keputusan Menkes tentang STBM, berbagai pihak masih merasa belum mantap untuk segera terjun menggerakkan masyarakat mewujudkan kondisi sanitasi total.

Open Defecation Free (ODF) adalah kondisi ketika setiap individu dalam komunitas tidak buang air besar sembarangan, Pembuangan tinja yang tidak memenuhi syarat sangat berpengaruh pada penyebaran penyakit berbasis lingkungan, sehingga untuk memutuskan rantai penularan ini harus dilakukan rekayasa pada akses ini. Agar usaha tersebut berhasil, akses masyarakat pada jamban (sehat) harus mencapai $100 \%$ pada seluruh komunitas. Sedangkan Desa/Kelurahan ODF (Open Defecation Free) adalah Desa/kelurahan yang 100\% masyarakatnya telah buang air besar di jamban sehat, yaitu mencapai perubahan perilaku kolektif terkait Pilar 1 dari 5 pilar Sanitasi Total Berbasis Masyarakat.(http://warungbidan.blogspot.co.id ).

Sebagai upaya untuk mewujudkan desa ODF telah dijelaskan dalam Peraturan Pemerintah No.3 Tahun 2014 pada pasal 12 bahwa dalam 
penyelenggaraan Sanitasi Total Berbasis Masarakat (STBM) meliputi penciptaan lingkungan yang kondusif, peningkatan kebutuhan sanitasi, dan peningkatan penyediaan akses sanitasi. Selanjutnya dalam ayat tiga disebutkan bahwa penciptaan lingkungan yang kondusif sebagaimana dimaksud pada ayat (2) huruf a merupakan upaya menciptakan kondisi yang mendukung tercapainya kondisisanitasi total melalui dukungan kelembagaan, regulasi, dan kemitraan dari Pemerintah, masyarakat, lembaga swadaya masyarakat, institusi pendidikan, institusi keagamaan dan swasta. (PP No.3, 2014). Salah satu upaya yang dapat dilakukan antara lain dengan program "Pemilikan Jamban Sehat Keluarga (PJSK)" yang mampu dapat dilakukan oleh masyarakat desa untuk mendapatkan jamban sehat.

Kemiskinan juga yang menyebabkan ketidak-mampuan masyarakat untuk memiliki jamban sehat dan layak. Berdasar data Desa Pojok tahun 2016 bahwa jumlah keluarga yang memiliki jamban sehat hanya 2.024 kepala keluarga dari jumlah Kepala Keluarga secara keleluruhan 2.839 Kepala Keluarga. (Data Desa Pojok, 2016) Ketiga, pendidikan yang relative rendah menyebabkan tingkat kesadaran masyarakat akan pentingnya hidup sehat juga berbanding lurus. Kombinasi dari tiga faktor tersebut kemudian membentuk pola pikir masyarakat secara turun-temurun yang tidak peduli akan perlunya sanitasi yang baik. Data dari Desa Pojok menunjukkan bahwa penduduk yang berpendidikan "sarjana" sejumlah 572 orang terdiri dari berpendidikan S1 sebanyak 536 orang atau $18,8 \%$, berpendidikan S2 sebanyak 31 orang atau 1,0 \% dan yang bergelar Doktor sebanyak 5 orang atau $0,1 \%$. Selebihnya masih banyak masyarakat yang berpendidikan menengah sebanyak 1.485 orang atau $52 \%$, pendidikan rendah dan atau tidak berpendidikan sebanyak 1.548 orang atau $54 \%$. Kondisi tersebut dapat menyebabkan belum tumbuhnya kesadaran mastyarakat untuk membudayakan hidup sehat melalui menggunakan jamban sehat di keluarganya masing-masing. Selain tingkat pendidikan yang rendah juga adanya keterbatasan petugas kesehatan untuk dapat melakukan sosialisasi tentang pentingnya hidup sehat dan pentingnya menggunakan jamban yang sehat kepada masyarakat.

Oleh karena itu dibutuhkan suatu terobosan yang mampu menangani permasalahan-permasalahan lingkungan di atas secara komprehensif. Hal ini mengingat keberhasilan pembangunan nasional khususnya di sektor kesehatan sangat dipengaruhi oleh ketersediaan sumber daya manusia yang sehat, terampil, dan ahli serta disusun dalam suatu program kesehatan dengan perencanaan terpadu yang didukung oleh data dan informasi epidemiologi yang valid (Departemen Kesehatan RI, 2005). Sebagai langkah konkret dalam upaya mewujudkan desa Open Defecate Free (ODF) di wilayah kerjanya, Desa Pojok Kecamatan Garum Kabupaten Blitar. Kelompok kerja Desa Simpatik bersama Puskesmas Kecamatan garum menginisiasi sebuah program yang disosialisasikan kepada masyarakat sebagai kebijakan yang dimanifestasikan dalam program bertajuk "Pemilikan Jamban Sehat Keluarga (PJSK)". Program Pemilikan Jamban Sehat tiap Keluarga bertujuan untuk membantu masyarakat untuk dapat memiliki jamban yang layak dan sehat disetiap keluarga.

Terdapat 50 besar kompetisi inovasi pelayanan publik (SiNovik) 2015 yang diselenggarakan oleh Kementerian Pendayagunaan Aparatur Negara dan Reformasi Birokrasi Republik Indonesia dan menjadi salah satu bagian penting dari program yang akan diajukan ke United Nations Public Service 
Awards (UNPSA). Oleh karena itu penulis berketetapan untuk meneliti upaya mewujudkan desa Open Defecate Free (ODF) di Kecamatan Garum Kabupaten Blitar pada umumnya dan di Desa Pojok pada khususnya.

Penelitian terdahulu dilakukan oleh Tatik Setianingsih melakukan penelitian dengan judul "Mendobrak keterbatasan masyarakat: Mewujudkan desa Open defacation Free di Kabupaten Banyuwangi" melalui inovasi dengan program "Pergunakan Jamban Sehat, Rakyat Aman" atau disingkat dengan akronim "Pujasera". Fokus kajian yaitu pendekatan, strategi, outpun dan kendalanya dari program Pujasera. Berbeda dengan penelitian ini yang berfokus pada geografis masyarakat, sosiologi masyarakat dan upaya mewujudkan desa Open Defecate Free (ODF) Desa Pojok Kecamatan Garum Kabupaten Blitar Jawa Timur.

\section{METODE}

Jenis penelitian dalam penelitian ini adalah kualitatif. Riset kualitatif merupakan suatu penelitian mendalam (in-depth), berorientasi pada kasus dari sejumlah kasus, termasuk satu stusi kasus (William \& Monge, 2001:293). Penelitian ini dilakukan dengan aksi partisipatif (participatory action research), yaitu penelitian yang melibatkan secara aktif semua pihakpihak yang relevan dalam mengkaji tindakan yang sedang berlangsung dalam rangka melakukan perubahan dan perbaikan ke arah yang lebih baik (Affandi et all., 2014:91).

Dari aspek pembahasannya penelitian ini merupakan penelitian diskriptif yaitu suatu penelitian yang hanya melukiskan, memaparkan dan melaporkan suatu keadaan, suatu obyek atau peristiwa tanpa menarik kesimpulan umum. Kartono (1990,29). Sangat memungkinkan peneliti untuk mengumpulkan informasi yang detail dan kaya yang mencakup dimensi sebuah kasus. Pendekatan yang digunakan dalam penelitian ini adalah pendekatan Paedagogis, yaitu suatu pendekatan yang dilakukan dari sudut pandang ilmu Pendidikan. Lokasi dari penelitian ini adalah Desa Pojok Kecamatan Garum Kabupaten Blitar Jawa Timur. Adapun fokus dari penelitian ini adalah geografis, sosiologis dan upaya mewujudkan desa Open Defecate Free (ODF) Desa Pojok Kecamatan Garum Kabupaten Blitar Jawa Timur.

Penelitian ini merupakan jenis penelitian lapangan (field research) dan masuk dalam kategori penelitian kualitatif, dimana penelitian lebih diarahkan untuk memahami fenomena-fenomena yang terkait dengan rumusan masalah.

Metode Pengumpulan Data. Teknik wawancara: yaitu proses memperoleh keterangan untuk tujuan penelitian dengan cara tanya jawab sambil bertatap muka antara pewawancara dengan informan, Wawancara yang dipakai adalah wawancara tidak terstruktur dan wawancara mendalam. Teknik Observasi; Observasi yang dipergunakan adalah Observasi Partisipatif yaitu metode pengumpulan data yang dipergunakan untuk menghimpun data penelitian melalui pengamatan dan pengindraan. Teknik Dokumentasi adalah salah satu metode pengumpulan data yang dipergu nakan dalam penelitian sosial dengan menelusuri data historis.

Proses mengorganisasikan dan mengurutkan data kedalam pola kategori dan satuan uraian dasar dapat dirumuskan dengan hipotetis kerja seperti yang disarankan oleh data. Moloeng (2005:103). Analisis data yang dimaksud adalah 
untuk mencari dan menata secara sistematis hasil observasi, wawancara, catatancatatan dan dokumentasi untuk meningkatkan peneliti terhadap persoalan yang sedang diteliti dengan cara reduksi data, penyajian data dan penarikkan kesimpulan/verifikasi.

\section{HASIL}

Berdasar dara dari Desa Pojok menunjukan bahwa keadaan Demografi masyarakat Desa Pojok terdiri 2.839 Kepala Keluarga terdiri dari 10.136 orang. Dari jumlah kepala keluarga tersebut yang berpendidikan "sarjana" sejumlah 572 orang terdiri dari berpendidikan S1 sebanyak 696 orang atau 6,8\%, berpendidikan S2 sebanyak 31 orang atau 0,3 \% dan yang bergelar Doktor sebanyak 5 orang atau $0,04 \%$. Selebihnya berpendidikan menengah (SLTP dan SLTA) ada pula yang masih mengenyam di pendidikan dasar saja atau bahkan tidak berpendidikan. Diantara masyarakat yang masih berpendidikan menengah sebanyak 1.359 orang atau 13,4 \%, pendidikan rendah (TK, SD, dan atau tidak berpendidikan) sebanyak 7.987 orang atau $78,7 \%$.

Masyarakat masih ada nyang biasa buang air besar di sungai, meskipun juga memiliki jamban sendiri. Selain itu juga difungsikan sebagai tempat memenuhi kebutuhan hidup seperti mencuci pakaian, memandikan hewan, dan irigasi. Sedangkan dari sisi mata pencaharian, masyarakat Desa Pojok mayoritas sebagai petani. Sesuai data Desa Pojok dari jumlah total penduduk Desa Pojok 10.136 orang, sebanyak 2.860 sebagai keluarga petani, lainnya antara lain sebagai Pegawai Negeri, dagang, wiraswasta, ada pula sebagai Tenaga Kerja Indonesia (TKI).

Sosio masyarakat Desa Pojok dalam berinteraksi sosisal sangat dipengaruhi oleh kondisi lingkungan. Karena 6 dari tujuh dusun di Desa Pojok pemukiman warga dialiri oleh sungai besar maupun kecil. Sungai tersebut secara praktis selalu digunakan untuk pengairan sawah atau irigasi, mengairi kolamkolam pribadi, namun ternyata juga digunakan untuk kebutuhan rumah seharihari. Baik mandi, mencuci pakaian maupun buang air besar juga banyak dilakukan di sungai. Beberapa peternak yang dekat dengan sungaipun juga sering memandikan hewan piaraannya khususnya Sapi.

Prilaku masyarakat Desa Pojok cenderung saling mempengaruhi satu sama lain diantaranya dalam hal bercocok tanam karena adanya kesamaan profesi dan musim; Pendidikan karena kemampuan masyarakat dalam menempuh pendidikan terbatas, sehingga lebih banyak bekerja dan tidak ada upaya untuk melanjutkan ke jenjang yang lebih tinggi; Prilaku masyarakat buang air besar sembaranganpun menjadi kebiasaan yang diikuti oleh masyarakat sebagai suatu kebersamaan.

Sesuai data Desa Pojok jumlah keluarga sebanyak 2.839 baru sebanyak 2.024 Keluarga yang mempunyai jamban keluarga. Dengan demikian terdapat 815 Kepala keluarga yang belum memiliki jamban keluarga. Hal tersebut menjadi tanggungjawab kepala desa bersama kaderdesa dan tokoh masyarakat serta sangat perlu keterlibatan seluruh masyarakat secara langsung dalam merumuskan upaya untuk menemukan jalan keluarnya. Upaya mewujudkan Desa Open Defecation Free (ODF) di Desa Pojok kecamatan Garum Kabupaten Blitar dilakukan melalui beberapa cara antara lain memberdayakan masyarakat melalui pembentukan Kelompok Desa (Pokja) Simpatik, sosialisasi Open Defecation Free (ODF),

360 BRILIANT: Jurnal Riset dan Konseptual Volume 3 Nomor 3, Agustus 2018 
pemetaan dan pemicuan Jamban keluarga. Output dari upaya mewujudkan Open Defecation Free (ODF) di Desa Pojok tersebut adalah terjadinya pokja Simpatik, terlaksananya sosialisasi Open Defecation Free (ODF) di Desa Pojok, adanya pemetaan dan pemicuan Jamban keluarga di Desa Pojok guna meningkatkan kehidupan sosial masyarakat yang lebih beradab dan bermartabat. Munculnya kesadaran akan pentingnya menjaga kesehatan baik kesehatan diri maupun lingkungan.

Munculnya inovasi program "Pemilikan Jamban Sehat Keluarga (PJSK)" bermula dari musyawarah yang dilakukan lintas sektoral yang diinisiasi oleh petugas Puskesmas Garum dan Pokja Simpatik drsa Pojok. Musyawarah lintas sektor tersebut diikuti oleh seluruh staf Pusksmas Garum serta perwakilan dari Dinas Kesehatan Kabupaten Blitar, bu Camat Garum, tokoh agama, dan stakeholder terkait lainnya. Setelah melakukan pertemuan dan diskusi yang intensif, muncul suatu terobosan inovasi yang diberi nama "Pemilikan Jamban Sehat Keluarga (PJSK). Dilanjutkan pertemuan tim disetiap dusun bersama perwakilan masyarakat di setiap RT dan RW.

Dibentuknya tim atau satuan tugas di setiap dusun dibentuk agar program tersebut dapat berjalan efektif. Pertama, Kader "Pemilikan Jamban Sehat Keluarga (PJSK) yang terdiri staf puskesmas Garum, kepala dusun, tokoh masyarakat dan Pokja desa Simpati sebagai pendamping dalam proses pembuatan jamban sehat. Kedua, membentuk satgas Open Defecation Free (ODF) di masing-masing dusun yang terdiri dari tokoh masyarakat dan tokoh agama sebagai pengawas pelaksana. Ketiga membangun kemitraan dengan kontraktor sebagai pelaksana pengerjaan fisik pembuatan jamban sehat. Keempat, membentuk tiga kelompok arisan jamban sehat di masing-masing dusun yang dilaksanakan setiap satu bulan sekali dengan anggota semua warga yang belum memiliki jamban dan dipimpin oleh kepala dusun. Sehingga setiap bulan dari tujuh dusun yang melakukan pembangunan Jamban keluarga sebanyak 21 buah, atau 252 setiap tahunnya. Dengan demikian diharapkan sebanyak 815 keluarga yang belum memiliki jamban sehat dapat diselesaikan selama tiga tahun yaitu mulai tahun 2018 sampai dengan tahun 2021. Pada tahun 2018 saat penelitian dilakukan sudah terdapat satu dusun yang telah terwujud Open Defecation Free (ODF). Selain letak georafisnya terdekat dengan Kota Blitar juga dipengaruhi dari tingkat pendidikan penduduknya banyak yang pendidikan menengah dan tinggi.

Kendala yang menyertai upaya tersebut tentu ada antara lain adalah: pertama, kendala waktu. Pemicuan tidak dapat dilaksanakan pada siang hari, karena melibatkan beberapa pemangku program inovasi dari petugas kesehatan dan tokoh masyarakat yang sering bersamaan kegiatannya. Selain itu sebagian besar masyarakat pada siang hari rata-rata bekerja sebagai petani, sehingga harus dilaksanakan di luar jam kerja (malam hari). Kedua, kendala sumber daya manusia, tidak adanya tenaga konsultan teknis dalam pengerjaan. Upaya mengatasi kendala ini dilakukan dengan kerjasama dengan kontraktor terkait teknik pembuatan jamban sehat. Ketiga, kendala kultural. Masyarakat sulit meninggalkan kebiasaan buang air besar di sungai karena faktor kebiasaan dan budaya walaupun sudah memiliki jamban. Untuk itu perlu pendekatan persuasif dengan mencontohkan beberapa dampak yang riil. Keempat, kendala ekonomi Kemiskinan menciptakan stigma masyarakat bahwa 
inovasi harus berupa bantuan. Solusi konkrit kendala ini dilakukan melalui arisan. Kelima, kendala psikologis. Adanya keraguan akan keberhasilan inovasi "Pemilikan Jamban Sehat Keluarga (PJSK) dari pemangku program yang terlibat sehingga untuk lebih memantapkan kepada masyarakat bahwa program ini dapat betul-betul berhasil.

Dengan pola komunikasi yang baik dan lebih sederhana, terbukti masyarakat Desa Pojok Kecamatan Garum dapat bekerjasama dengan baik dalam upaya mewujudkan desa Open Defecation Free (ODF). Masyarakat ikut beperan aktif untuk meningkatkan perilaku hidup bersih dan sehat. Kesehatan bukan tanggung jawab petugas kesehatan atau pemerintah saja tetapi tanggung jawab seluruh masyarakat untuk melindungi dan mengatasi dirinya sendiri terutama kesehatan lingkungan. Dengan demikian dapat dikatakan bahwa upaya mewujudkan desa Open Defecation Free (ODF) telah mampu merubah pola pikir masyarakat melalui kebutuhan masyarakat itu sendiri.

\section{PEMBAHASAN}

Mata pencaharian, masyarakat di Desa Pojok yang mayoritas sebagai petani, yaitu jumlah total penduduk Desa Pojok 10.136 orang, sebanyak 2.860 sebagai keluarga petani. Dengan tingkat pendidikan yang didominasi pada tingkat pendidikan rendah berdampak pada prilaku masyarakat dalam memanfaatkan alam (sungai) untuk tempat memenuhi kebutuhan hidup seperti mencuci pakaian, memandikan hewan, irigasi juga untuk buang air besar. Hal tersebut sesuai dengan paparan Wilujeng bahwa ciri-ciri desa yaitu sebagai berikut: (1) Di dalam masyarakat pedesaan memiliki hubungan yang lebih mendalam dan erat bila dibandingkan dengan masyarakat pedesaan lainnya di luar batas-batas wilayahnya; (2) System kehidupan umumnya berkelompok dengan dasar kekeluargaan (gemeinschaft atau paguyuban); (3) Sebagian besar warga masyarakat hidup dari pertanian. Pekerjaan-pekerjaan yang bukan pertanian merupakan pekerjaan sambilan (part time) yag biasa mengisi waktu luang; (4) Masyarakat tersebut homogen, seperti dalam hal mata pencaharian, agama, adatistiadat dan sebagainya. (Wilujeng, 2012)

Prilaku masyarakat Desa Pojok cenderung saling mempengaruhi satu sama lain diantaranya dalam hal bercocok tanam karena adanya kesamaan profesi dan musim; Pendidikan karena kemampuan masyarakat dalam menempuh pendidikan terbatas, sehingga lebih banyak bekerja dan tidak ada upaya untuk melanjutkan ke jenjang yang lebih tinggi; Buang air besar sembaranganpun menjadi kebiasaan yang diikuti oleh masyarakat sebagai suatu kebersamaan. Hal tersebut sesuai dengan konsep Kristiyanto (2017) bahwa ciri-ciri masyarakat pedesaan meliputi: (1) jumlah penduduk di perkotaan jauh lebih padat dibandingkan dengan di pedesaan, Lingkungan hidup di di pedesaan yang sangat tradisional; (2) mata pencaharian di pedesaan masih mengandalkan alam sekitar desa, seperti nelayan, petani, peternak hewan; corak masyarakat desa sangat mengutamakan sosial live nya; Pola interaksi sosisal antara dua individu atau lebih dimana kelakuan individu yang satu mempengaruhi, mengubah, atau memperbaiki kelakuan individu lain atau sebaliknya.

Upaya mewujudkan Desa Open Defecation Free (ODF) di Desa Pojok Kecamatan Garum kabupaten Blitar dilakukan melalui beberapa cara antara lain 
memberdayakan masyarakat melalui pembentukan kelompok kerja (Pokja) Simpatik, sosialisasi Open Defecation Free (ODF), pemetaan dan pemicuan Jamban keluarga, pembentukan tim Open Defecation Free (ODF) di setiap dusun, dan melekukan kerja sama dengan pihak terkait. Hal tersebut telah sesuai dengan Peraturan Pemerintah No.3 Tahun 2014 pada pasal 12 bahwa dalam penyelenggaraan Sanitasi Total Berbasis Masarakat (STBM) meliputi penciptaan lingkungan yang kondusif, peningkatan kebutuhan sanitasi, dan peningkatan penyediaan akses sanitasi. Selanjutnya dalam ayat tiga disebutkan bahwa penciptaan lingkungan yang kondusif sebagaimana dimaksud pada ayat (2) huruf a merupakan upaya menciptakan kondisi yang mendukung tercapainya kondisi sanitasi total melalui dukungan kelembagaan, regulasi, dan kemitraan dari Pemerintah, masyarakat, lembaga swadaya masyarakat, institusi pendidikan, institusi keagamaan dan swasta. (PP No.3, 2014).

\section{KESIMPULAN}

Kesimpulan dalam penelitian ini bahwa demografi masyarakat Desa Pojok berjumlah $2.839 \mathrm{KK}$, sarjana sejumlah 572 orang terdiri dari berpendidikan S1 sebanyak 536 orang, S2 sebanyak 31 orang atau 1,0 \% dan Doktor sebanyak 5 orang atau $0,1 \%$. Selebihnya berpendidikan menengah sebanyak 1.485 orang atau $52 \%$, pendidikan rendah dan atau tidak berpendidikan sebanyak 1.548 orang atau $54 \%$; Sosiologi masyarakat Desa Pojok interaksi sosisal sangat dipengaruhi oleh kondisi lingkungan, prilaku individu cenderung saling mempengaruhi satu sama lain; Upaya mewujudkan Desa Open Defecation Free (ODF) di Desa Pojok Kecamatan Garum kabupaten Blitar dilakukan melalui beberapa cara antara lain memberdayakan masyarakat melalui pembentukan Kelompok Desa (Pokja) Simpatik, sosialisasi Open Defecation Free (ODF), pemetaan dan pemicuan Jamban keluarga. Kesimpulan bahwa demografi masyarakat Desa Pojok masih berpendidikan menengah dan rendah, Sosiologi masyarakat didominasi petani dengan lingkungan pedesaan, sedangkan upaya mewujudkan Open Defecation Free (ODF) dilakukan dengan bekerjasama semua pihak guna meningkatkan kehidupan sosial masyarakat yang lebih beradab dan bermartabat.

\section{SARAN}

Kepada tokoh masyarakat dan petugas kesehatan harus memperhatikan waktu yang pertemuan di luar jam kerja (malam hari) karena mayoritas masyarakat senagai petani dan melakukan pendekatan persuasif meninggalkan kebiasaan buang air besar di sungai. Kepada masyarakat desa Pojok Pojok Kecamatan Garum diharapkan dapat ikut beperan aktif dalam mewujudkan desa Open Defecation Free (ODF) untuk meningkatkan perilaku hidup bersih dan sehat.

\section{DAFTAR RUJUKAN}

Affandi, Agus., et all. 2014. Modul Participatory Action Research (PAR): Untuk Pengorganisasian Mayarakat. Surabaya: LPPM UINSA.

Anonim. Pengertian Sosiologi Pedesaan. (Online), (https://tipsserbaserbi. blogspot.co.id) diakses pada 25 Januari 2018.

Departemen Kesehatan Republik Indonesia. 2005. Pembangunan Kesehatan. Jakarta: Pusdatin Depkes RI. 
Harwantiyoko., \& F, KN. 1997. Ilmu Sosial Dasar. Jakarta: Gunadarma, 1997.

Anonim. Konsep Dasar Open Defecation Free. (Online), (http://warungbidan.blogspot.co.id/2016/05/konsep-dasar-open-defecatio n-free-odf). diakses pada 25 Januari 2018.

Kartono, K. 1990. Pengantar Metodologi Riset Sosial. Bandung: Mandar Maju.

Kepmenkes No 852 tahun 2008 tentang Strategi Nasional Sanitasi Total Berbasis Masyarakat.

Kristiyanto. 2017. Makalah Masyarakat Pedesaan dan Perkotaan. (Online), (https://kristiyanto256.wordpress.com), diakses pada 28 Januari 2018.

Moloeng, Lexy. 2005. Metodologi Penelitian Kualitatif, Bandung: Remaja Rosdakarya.

Peraturan Pemerintah No.3 Tahun 2014.

Sururudin. 2008. Demografi. (Online), (https://sururudin.wordpress.com, demografi/), diakses pada 2 Februari 2018.

United Nations Department of Economics and Social Affairs (UNDESA). 2007. Governance for the Millennium Development Goals: Core Issues and Good Practices. $7^{\text {th }}$ Global.

William, F., \& Monge, PR. 2001. Reasoning With Statistic: How to Read Quantitative Studies. New York: Harcourt.

Wilujeng, D. 2012. Makalah Masyarakat Desa. (Online), (ttps://blog.ub.ac.id/mistikdwiwilujeng), diakses pada 25 Januari 2018. 